\title{
Radical Scavenging and Antioxidant Potential of Nuts and Leaves Extracts of Semecarpus anacardium (L.)
}

\author{
Nachiketa Barman ${ }^{1}$, Archna Sharma1, Ashwani Kumar ${ }^{2}$ \\ ${ }^{1}$ Department of Botany, Vedic Girls P. G. College, University of Rajasthan, Jaipur, India; ${ }^{2}$ Laboratory of Bioactive Compounds and \\ Algal Biotechnology, Department of Botany, University of Rajasthan, Jaipur, India. \\ Email: nachiketabarman@gmail.com
}

Received June $13^{\text {th }}, 2013$; revised July $15^{\text {th }}, 2013$; accepted July $31^{\text {st }}, 2013$

Copyright (C) 2013 Nachiketa Barman et al. This is an open access article distributed under the Creative Commons Attribution License, which permits unrestricted use, distribution, and reproduction in any medium, provided the original work is properly cited.

\begin{abstract}
In the present investigation, antioxidant activity of the crude extracts from nuts and leaves of S. anacardium was carried out. The antioxidant potential of various extracts (ethanol, acetone and aqueous) of $S$. anacardium was determined by using DPPH assay, ABTS assay and metal chelating activity assay. Among the extracts the ethanol extract of nut showed significant scavenging activity (DPPH-88.73 \pm 2.26 ; ABTS assay $-81.65 \pm 1.57$ and metal chelating activity $-72.37 \pm 2.26$ ) compared with antioxidant controls, ascorbic acid and BHA respectively. The findings of the present investigation suggest that the $S$. anacardium extracts can prove to be a potent source of biologically active compounds that can be further subjected to isolation of therapeutic antioxidant agents.
\end{abstract}

Keywords: Semecarpus anacardium; Anacardiaceae; Antioxidant Activity

\section{Introduction}

Reactive oxygen species (ROS) result in oxidative stress causing extensive damage to cellular biomolecules contributing to the increased risk for several chronic disorders. The most effective way to combat oxidative stress is the use of antioxidants that have been increasingly promoted in the scientific literature as beneficial components in reducing the risk [1]. Antioxidants interfere with the oxidation process that acts by one or more mechanisms like free radical-scavenging, quenching of singlet oxygen, inhibiting lipid per-oxidation, chelating catalytic metal ions and form complexes with DNA [2,3]. Although synthetic antioxidants seem to be promising, many drugs such as butylated hydroxyl anisole (BHA), butylated hydroxyl toluene (BHT), tertiary butylated hydroquininone (THBQ) and propyl gallate (PG) have carcinogenic potential and adverse side effects. Hence, there has been an upsurge in discovery of new, safe and effective antioxidants to substitute them with naturally occurring antioxidants [4].

Plants and plant based medications have been man's prime therapeutic tools due to the presence of various complex substances that show a striking structural diversity. These biochemical products which are found as secondary metabolites in plants are extractable and act as a vast source of natural antioxidant which can help to prevent the onset and counteract progression of oxidative stress [5]. Furthermore, natural antioxidants are perceived as efficient, safe, cost effective and affordable in comparison with synthetic antioxidants that might serve as leads for the development of novel drugs and in food industry to prolong the shelf life of foods, especially those rich in polyunsaturated fats [6]. Traditionally used natural antioxidants are already exploited but, there is still a demand to explore more information concerning the antioxidant potential of plant species.

Semecarpus anacardium (Anacardiaceae), commonly known as marking nut tree and bhallataka is used as an herbal drug in Ayurvedic and Unani medicines for being caustic, astringent, antirheumatiic, vesicant and used in anorexia, cough, asthma, indigestion, ulcer, piles and various nervous diseases $[7,8]$. Phytochemical studies revealed the presence of phenolic compounds, bhilawanols [9], biflavonoids [10,11], anacardic acid [12], alkenyl catechols [13]. The nut milk extract has been reported to possess several biological activities such as anti-arthritis [14], antispermatogenic [15], antimicrobial [16,17] and mutagenic properties [18]. Therefore, the current communication is an attempt to investigate the antioxidant potential of Semecarpus anacardium. 


\section{Material and Methods}

\subsection{Plant Material}

The leaves and nuts of Semecarpus anacardium were collected from West Bengal in the month of July and were authenticated from National Institute of Ayurveda (NIA), Jaipur, Rajasthan. A voucher specimen was submitted in the herbarium, Department of Botany, University of Rajasthan (RUBL 20625). The plant materials were shade dried and powdered.

\subsection{Preparation of Plant Extract}

The powdered plant material $(300 \mathrm{~g})$ was soxhlet extracted with acetone, chloroform, ethanol and water in succession for $16-18 \mathrm{hr}$ in each solvent. Each of the extracts, thus obtained, was filtered and dried in vacuo. The dried semi-solid mass thus obtained was stored at $4^{\circ} \mathrm{C}$ in the refrigerator until further study.

\subsection{Determination of Antioxidant Assay}

The antioxidant potential of various extracts (ethanol, chloroform, acetone and aqueous) of $S$. anacardium stem were determined by using DPPH assay (1,1-diphenyl-2picrylhydrazyl radical), ABTS assay (2,2'-anizo-bis(3ethylbenzothiazoline-6-sulfonic acid) and metal chelating activity assay. BHA (Butylated Hydroxy Anisole) and Ascorbic acid was used as positive control. All the experiments were repeated thrice. The results are expressed as means $\pm \mathrm{SE}$ of three experiments.

\subsubsection{DPPH Free Radical Scavenging Activity}

The free radical scavenging activity of crude extracts of $S$. anacardium was determined in vitro, by using the 1,1diphenyl-2-picrylhydrazyl (DPPH) assay [19]. A stock solution of $0.1 \mathrm{ml}$ of DPPH was prepared in ethanol. This solution was mixed with equal volume of various test extracts $(100 \mu \mathrm{g} / \mathrm{ml})$ of leaves and nuts of S. anacardium. The reaction was allowed to be completed in dark for 20 minutes. The absorbance was measured at $517 \mathrm{~nm}$ using a spectrophotometer. The experiments were performed in triplicate and $\%$ of scavenging activity was calculated by using following equation; [(Absorbance control - Absorbance $\left._{\text {sample }}\right) /$ Absorbance control $] \times 100$.

\subsubsection{ABTS Assay}

The ability of the extracts (leaves and nuts) of S. anacardium to scavenge ABTS was carried out by the method of [20]. In this assay, ABTS was dissolved in water to a 7 $\mathrm{mM}$ concentration. ABTS radical cation $\left(\mathrm{ABTS}^{+}\right)$was produced by reacting ABTS stock solution with $2.45 \mathrm{mM}$ potassium persulfate (final concentration) and allowing the mixture to stand in the dark at room temperature for $12 \mathrm{~h}$ before use. Absorbance of $2 \mathrm{mM}$ ABTS solution in potassium persulfate was recorded at $734 \mathrm{~nm}$ by spectrophotometer. $0.1 \mathrm{ml}$ of the extracts $(0.01$ to $0.5 \mathrm{mg} / \mathrm{ml})$ was added to $1 \mathrm{ml}$ of ABTS solution and absorbance change of ABTS solution was recorded after $4 \mathrm{~min}$. The scavenging ability of ABTS was determined as [(Absorbance $_{\text {control }}-$ Absorbance $_{\text {sample }} / /$ Absorbance $\left._{\text {control }}\right] \times$ 100.

\subsubsection{Metal Chelating Activity}

The chelating activity of leaves and nuts extracts of $S$. anacardium for ferrous ions $\mathrm{Fe}^{2+}$ was measured according to the method of [21]. To $0.5 \mathrm{~mL}$ of extract, $1.6 \mathrm{~mL}$ of deionized water and $0.05 \mathrm{~mL}$ of $\mathrm{FeCl}_{2}(2 \mathrm{mM})$ was added. After $30 \mathrm{~s}, 0.1 \mathrm{~mL}$ ferrozine $(5 \mathrm{mM})$ was added. Ferrozine reacted with the divalent iron to form stable magenta complex species that were very soluble in water. After $10 \mathrm{~min}$ at room temperature, the absorbance of the $\mathrm{Fe}^{2+}$-Ferrozine complex was measured at $562 \mathrm{~nm}$. The experiments were performed in triplicate and \% of scavenging activity was calculated by using following equation; $\left[\left(\right.\right.$ Absorbance $_{\text {control }}-$ Absorbance $\left._{\text {sample }}\right) /$ Absorbance $\left._{\text {control }}\right] \times 100$.

\section{Result and Discussion}

Free radicals due to environmental pollutants, radiation, chemicals, toxins and physical stress results in oxidative stress causing damage to cell structures, DNA, lipids and proteins that increases risk of different disease in humans [22]. Currently available synthetic antioxidants prompt negative health effects and show low solubility. Natural antioxidants from plants can provide unique therapeutic properties as a supplement in drug discovery programs owing to their presumed safety and effectiveness [2]. A number of plants and their purified constituents have been screened for the present of biologically active metabolites with antioxidant activities [23-26].

The antioxidant potential of various extracts (ethanol, chloroform, acetone and aqueous) from nuts of $S$. anacardium were determined by using DPPH assay, ABTS assay and metal chelating activity assay and compared with that of the standard antioxidants ascorbic acid and BHA that were used as positive controls. All the tested samples showed high level of scavenging activity compared to the standards (Table 1). Among the extracts of the investigated parts of S. anacardium, the ethanol extract showed remarkable scavenging activity, (28.06 \pm 2.60 to $83.77 \pm 2.75$ ) followed by chloroform, acetone and water. Earlier studies have been carried out on the antioxidant activity of stem bark of S. anacardium [27,28].

In the present study, nut extract in ethanol of S.anacardium showed significant free radical scavenging activity (DPPH-88.73 \pm 2.26 ; ABTS assay-81.65 \pm 1.57 and metal chelating activity-72.37 \pm 2.26 ) when com- 
pared with the antioxidant control, ascorbic acid and BHA respectively (Table 1; Figures 1 and 2). The chloroform extracts exhibited distinguishing activity than acetone that displayed normal antioxidant activity. The leaf extracts of $S$. anacardium showed poor free radical scavenging activity $(69.48 \pm 2.05$ to $18.65 \pm 1.16)$. The water extracts showed minimum level of scavenging activity compared to other extracts and standards. The antioxidant activity of compounds is mainly due to their redox properties, that play important role in absorbing and neutralizing free radicals, quenching singlet and triplet oxygen, or decomposing peroxides, which may be related to the high amount of flavonoid and phenolic compounds in this plant extract [29]. Based on the results of our study and other previous studies, the findings validated traditional medicinal values and suggest that $S$. anacardium is potentially a good source of natural antioxidant agent.

Table 1. Antioxidant activity of nuts and leaves of $S$. anacardium.

\begin{tabular}{|c|c|c|c|c|}
\hline \multirow{2}{*}{ Plant parts } & \multirow{2}{*}{ Extracts } & \multicolumn{3}{|c|}{ Test Applied } \\
\hline & & DPPH & ABTS & Metal chelating activity assay \\
\hline \multirow{4}{*}{ Nuts } & Ethanol & $88.73 \pm 2.26$ & $81.65 \pm 1.57$ & $72.37 \pm 2.26$ \\
\hline & Acetone & $67.99 \pm 1.24$ & $69.03 \pm 2.56$ & $58.92 \pm 1.08$ \\
\hline & Chloroform & $72.57 \pm 2.43$ & $74.42 \pm 1.59$ & $64.80 \pm 2.10$ \\
\hline & Water & $39.07 \pm 1.17$ & $33.67 \pm 0.74$ & $26.54 \pm 0.88$ \\
\hline \multirow{4}{*}{ Leaves } & Ethanol & $69.48 \pm 2.05$ & $62.83 \pm 1.62$ & $58.42 \pm 2.11$ \\
\hline & Acetone & $52.23 \pm 2.98$ & $41.50 \pm 2.23$ & $42.36 \pm 3.13$ \\
\hline & Chloroform & $56.00 \pm 1.63$ & $49.45 \pm 2.44$ & $47.18 \pm 1.93$ \\
\hline & Water & $28.06 \pm 2.60$ & $24.54 \pm 3.02$ & $18.65 \pm 1.16$ \\
\hline \multirow{2}{*}{ Controls } & Ascorbic Acid & $88.23 \pm 1.80$ & $84.80 \pm 4.63$ & $79.10 \pm 1.68$ \\
\hline & BHA & $83.77 \pm 2.75$ & $80.32 \pm 1.57$ & $74.86 \pm 1.32$ \\
\hline
\end{tabular}

Abbreviations: BHA = Butylated Hydroxy Anisole; DPPH: 1,1-diphenyl-2-picrylhydrazyl radical; ABTS: 2,2'-anizo-bis(3-ethylbenzothiazoline-6-sulfonic acid). Each value represents mean $\pm \operatorname{SE}(n=3)$.

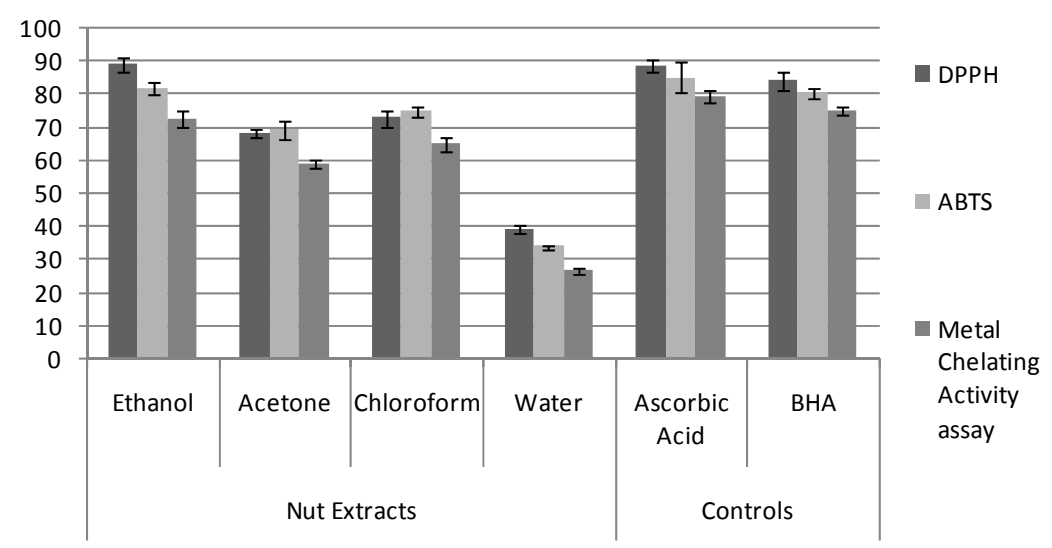

Figure 1. Antioxidant activity of nut extracts of $S$. anacrdium. Values represent treatment of three replicates \pm SE $(n=3)$.

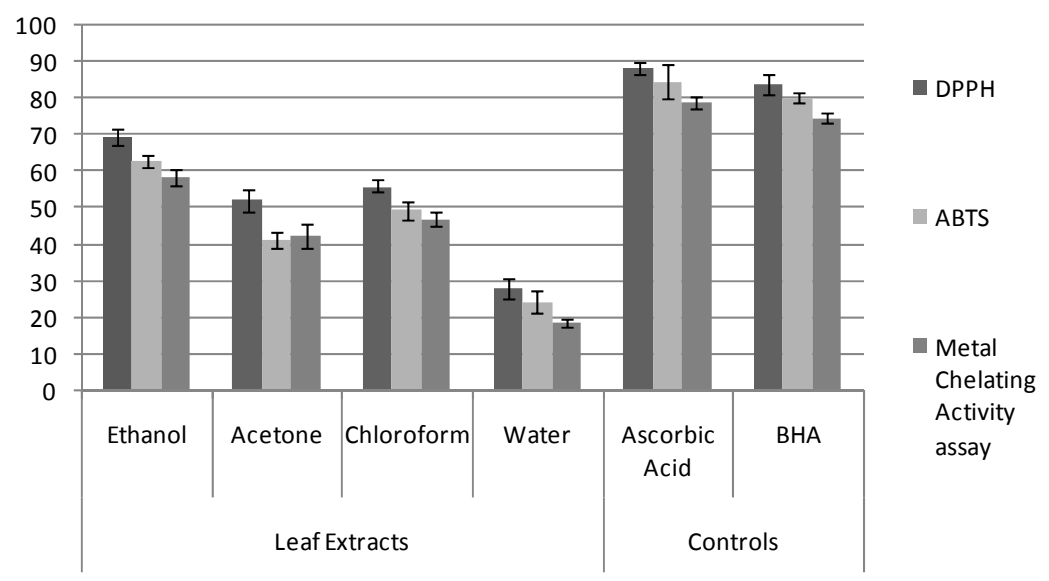

Figure 2. Antioxidant activity of leaf extracts of $S$. anacrdium. Values represent treatment of three replicates \pm SE $(n=3)$. 


\section{Conclusion}

The present investigation revealed that the various extracts from the nuts of $S$. anacardium exhibited significant free radical scavenging activity which explains the basis for its use in traditional medicines. However, the extracts of $S$. anacardium are further studied for its biologically active compounds that can be further subjected to isolation of therapeutic antioxidant agents.

\section{REFERENCES}

[1] R. Palaniswamy and P. R. Padma, "Free Radical Scavenging Activity of Majorana hortensis Leaves," Ancient Science of Life, Vol. 30, No. 4, 2011, pp. 96-99.

[2] W. Droge, "Free Radicals in the Physiological Control of Cell Function," Physiological Reviews, Vol. 82, No. 1, 2002, pp. 47-95.

[3] N. Ali, I. Shah, S. W. Shah, G. Ahmed, M. Shoaib, M. Junaid, W. Ali and Z. Ahmed, "Antioxidant and Relaxant Activity of Fractions of Crude Methanol Extract and Essential Oil of Artemisia macrocephala Jacquem," BMC Complementary and Alternative Medicine, Vol. 13, 2013, p. 96. doi:10.1186/1472-6882-13-96

[4] B. Mahdi-Pour, S. L. Jothy, L.Y. Latha, Y. Chen, S. Sasidharan and S. Dharmaraj, "Antioxidant Activity of Methanol Extracts of Different Parts of Lantana camara," Asian Pacific Journal of Tropical Medicine, Vol. 2, No. 12, 2012, pp. 960-965. doi:10.1016/S2221-1691(13)60007-6

[5] C. R. S. Al Nomaani, M. A. Hossain, A. M. Weli, Q. AlRiyami, J. N. Al-Sabahi and S. M. Rahman, "Chemical Composition of Essential Oils and in Vitro Antioxidant Activity of Fresh and Dry Leaves Crudeextracts of Medicinal Plant of Lactuca sativa L. Native to Sultanate of Oman," Asian Pacific Journal of Tropical Medicine, Vol. 3, No. 5, 2013, pp. 353-357. doi:10.1016/S2221-1691(13)60076-3

[6] S. Sannigrahi, U. K. Mazuder, D. K. Pal, S. Parida and S. Jain, "Antioxidant Potential of Crude Extracts and Different Fractions of Enhydra fluctuans Lour," Iranian Journal of Pharmaceutical Research, Vol. 9, No. 1, 2010, pp. $75-82$.

[7] K. M. Nardkarni, "Indian Material Medica," 3rd Edition, Popular Prakashan Private Ltd., Bombay, 1976, pp, 11191125.

[8] R. N. Chopra, "Indigenous Drugs of India," 2nd Edition, Academic Publishers, Calcatta. 1982.

[9] J. B. Lamture, N. M. Gondgaon, U. R. Nayak, B. K. Patwardhan and R. B. Ghooi, "Semecarpus anacardiumSeparation of the Bhilawanol A and Bhilawanol B and A Comparative Study of Their Growth Inhibitory Effect on Clostridium tetani and General Pharmacology," Bulletin of Haffkine Institute, Vol. 10, 1982, pp. 87-92.

[10] S. S. N. Murthy, "Jeediflavanone-A Biflavonoid from Semecarpus anacardium," Phytochemistry, Vol. 24, No. 5, 1985, pp. 1065-1070. doi:10.1016/S0031-9422(00)83184-2

[11] S. S. N. Murthy, "Semecarpuflavanone a New Biflava- none from Semecarpus anacardium," Proceeding of the Indian Academy of Science Chemical Sciences, Vol. 97, No. 1, 1986, pp. 63-70.

[12] R. R. Gil, L. Z. Lin, G. A. Cordell, M. R. Kumar, M. Ramesh, B. M. Reddy and A. V. N. Appa Rao, "Anacardoside from the Seeds of Semecarpus anacardium," Phytochemistry, Vol. 39, No. 2, 1995, pp. 405-407. doi:10.1016/0031-9422(94)00842-H

[13] T. R. Govindachari, B. S. Joshi, V. N. Kamat and N. Viswanathan, "The Phenolic Constituents of Semecarpus anacardium," Indian Journal of Chemistry, Vol. 9, 1971, pp. 1044-1046.

[14] B. Premalatha, V. Muthulakshmi, T. Vijayalakshmi and P. Sachdanandam, "Semecarpus anacardium Nut Extract Induced Changes in Enzymic Antioxidants Studied in Aflatoxin B1 Caused Hepatocellular Carcinoma Bearing Wistar Rats," International Journal of Pharmaceutics, Vol. 35, No. 3, 1997, pp. 161-166. doi:10.1076/phbi.35.3.161.13300

[15] A. Sharma, P. K. Verma and V. P. Dixit, "Effect of Semecarpus anacardium Fruits on Reproductive Function of Male Albino Rats," Asian Journal of Andrology, Vol. 5, No. 2, 2003, pp. 121-124.

[16] T. K. Mohanta, J. K. Patra, S. K. Rath, D. K. Pal and H. N. Thatoi, "Evaluation of Antimicrobial Activity and Phytochemical Screening of Oils and Nuts of Semicarpus anacardium L.f. Scient,” RES Essay, Vol. 2, No. 11, 2007, pp. 486-490.

[17] A. Sharma, N. Barman and M. Malwal, "Antimicrobial Efficacy of Nut Oil of Semecarpus anacardium: A Marking Nut Tree," Biotechnology, Vol. 9, No. 3, 2010, pp. 383-386. doi:10.3923/biotech.2010.383.386

[18] T. Vijayalakshmi, V. Muthulakshmi and P. Sachdanandam, "Effect of the Milk Extract of Semecarpus anacardium Nut on Adjuvant Arthritis: A Dose Dependent Study in Wistar Albino Rats," General Pharmacology, Vol. 27, No. 7, 1996, pp. 1223-1226. doi:10.1016/S0306-3623(96)00042-0

[19] W. Brand-Williams, M. E. Cuvelier and C. Berset, "Use of Free Radical Method to Evaluate Antioxidant Activity," Food Science and Technology, Vol. 28, No. 1, 1995, pp. 25-30.

[20] R. Re, N. Pellegrini, A. Proteggente, A. Pannala, M. Yang and C. Rice-Evans, "Antioxidant Activity Applying an Improved ABTS Radical Cation Decolorization Assay," Free Radical Biology \& Medicine, Vol. 26, No. 910, 1999, pp. 1231-1237. doi:10.1016/S0891-5849(98)00315-3

[21] J. Sabate, "The Contribution of Vegetarian Diets to Health and Disease: A Paradigm Shift," The American Journal of Clinical Nutrition, Vol. 78, 2003, pp. 502-507.

[22] M. Valko, D. Leibfritz, J. Moncol, M.T.D. Cronin, M. Mazur and J. Telser, "Free Radicals and Antioxidants in Normal Physiological Functions and Human Disease," The International Journal of Biochemistry \& Cell Biology, Vol. 39, No. 1, 2007, pp. 44-84. doi:10.1016/j.biocel.2006.07.001

[23] J. S. Deng, C. S. Chi, S. S. Huang, P. H. Shie, T. H. Lin and G. J. Huang, “Antioxidant, Analgesic, and Anti-In- 
flammatory Activities of the Ethanolic Extracts of Taxillus liquidambaricola," Journal of Ethnopharmacology, Vol. 137, No. 3, 2011, pp. 1161-1171. doi:10.1016/j.jep.2011.07.041

[24] J. He, B. Huang, X. Ban, J. Tian, L. Zhu and Y. Wang, "In Vitro and in Vivo Antioxidant Activity of the Ethanolic Extract from Meconopsis quintuplinervia," Journal of Ethnopharmacology, Vol. 141, No. 1, 2012, pp. 104-110. doi:10.1016/j.jep.2012.02.006

[25] R. S. Policegoudra, S. Saikia, J. Das, P. Chattopadhyay, L. Singh and V. Veer, "Phenolic Content, Antioxidant Activity, Antibacterial Activity and Phytochemical Composition of Garcinia lancifolia," Indian Journal of Pharmaceutical Sciences, Vol. 74, No. 3, 2012, pp. 268-271. doi:10.4103/0250-474X.106075

[26] S. S. Ali, N. Kasoju, A. Luthra, A. Singh, H. Sharanabasava, A. Sahu and U. Bora, "Indian Medicinal Herbs as
Sources of Antioxidants," Food Research International, Vol. 41, No. 1, 2008, pp. 1-15. doi:10.1016/i.foodres.2007.10.001

[27] C. Selvam, S. M. Jachak and K. K. Bhutani, "Cyclooxygenase Inhibitory Flavonoids from the Stem Bark of Semecarpus anacardium Linn," Phytotherapy Research, Vol. 18, No. 7, 2004, pp. 582-584. doi:10.1002/ptr.1492

[28] A. K. Sahoo, N. Narayanan, S. Sahana, S. S. Rajan and P. K. Mukherjee, "In Vitro Antioxidant Potential of Semecarpus anacardium L.," Pharmacologyonline, Vol. 3, 2008, pp. 327-335.

[29] S.L. Mishra, P. K. Sinhamahapatra, A. Nayak, R. Das and S. Sannigrahi, "In Vitro Antioxidant Potential of Different Parts of Oxoxylum indicum: A Comparative Study," Indian Journal of Pharmaceutical Sciences, Vol. 72, No. 2, 2010, pp. 267-269. doi:10.4103/0250-474X.65013 